\title{
Seed priming with selenium and zinc nanoparticles modifies germination, growth and yield of direct- seeded rice (Oryza sativa L.)
}

\section{Saju Adhikary}

Bidhan Chandra Krishi Viswavidyalaya

Benukar Biswas ( $\nabla$ kripahi@yahoo.com )

Bidhan Chandra Krishi Viswavidyalaya

Debashis Chakraborty

Indian Agricultural Research Institute

Jagadish Timsina

Global Evergreening Alliance

Srikumar Pal

Bidhan Chandra Krishi Viswavidyalaya

\section{Saon Banerjee}

Bidhan Chandra Krishi Viswavidyalaya

\section{Akbar Hossain}

Bangladesh Wheat and Maize Research Institute

\section{Sovan Roy}

Department of Science \& Technology and Biotechnology Government of West Bengal Jagadish Chandra Tarafdar

Ex-Scientist, Central Research Institute for Dryland Agriculture, 17E/361A, C. H. B., Jodhpur 342008, India

\section{Research Article}

\section{Keywords:}

Posted Date: February 16th, 2022

DOI: https://doi.org/10.21203/rs.3.rs-1305035/v1

License: (c) (1) This work is licensed under a Creative Commons Attribution 4.0 International License.

Read Full License 
1 Seed priming with selenium and zinc nanoparticles modifies germination,

2 growth, and yield of direct-seeded rice (Oryza sativa L.)

3

4 Saju Adhikarya, Benukar Biswas ${ }^{a,}$, Debashis Chakraborty ${ }^{b^{*}}$, Jagadish Timsina ${ }^{\mathrm{c}}$, Srikumar

$5 \quad$ Pal $^{\mathrm{d}}$, Jagadish Chandra Tarafdar ${ }^{\mathrm{e}}$, Saon Banerjee ${ }^{\mathrm{f}}$, Akbar Hossain $^{\mathrm{g}}$, Sovan Roy ${ }^{\mathrm{h}}$

6

7 aDepartment of Agronomy, Bidhan Chandra Krishi Viswavidyalaya, Mohanpur, Nadia, West

8 Bengal, India 741252.

$9 \quad{ }^{b}$ Division of Agricultural Physics, Indian Agricultural Research Institute, New Delhi 110012.

$10{ }^{\mathrm{c}}$ Global Evergreening Alliance, 1 Vision Drive, East Burwood, VIC 3151, Melbourne,

11 Australia, and Institute for Study and Development Worldwide, Sydney, NSW, Australia.

12 dDepartment of Agricultural Biochemistry, Bidhan Chandra Krishi Viswavidyalaya,

13 Mohanpur, Nadia, West Bengal, India 741252.

14 e Ex-Scientist, Central Research Institute for Dryland Agriculture, 17E/361A, C. H. B., 15 Jodhpur 342008, India and 32/E/2/1, Banamalipur Barasat, Kolkata, West Bengal, India 16700124.

$17{ }^{\mathrm{f} D e p a r t m e n t}$ of Agricultural Physics and Meteorology, Bidhan Chandra Krishi 18 Viswavidyalaya, Mohanpur, Nadia, West Bengal, India 741252.

19 gBangladesh Wheat and Maize Research Institute, Dinajpur 5200, Bangladesh.

$20{ }^{\mathrm{h}}$ Department of Science \& Technology and Biotechnology, Vigyan Chetana Bhavan, Kolkata, 21 West Bengal, India -700064.

*Correspondence authors: kripahi@yahoo.com (BB) and debashisiari@gmail.com (DC) 


\section{Abstract}

Direct-seeded rice (DSR) seeds are often exposed to multiple environmental stresses in the

field, leading to poor emergence, growth and productivity. Appropriate seed priming agents may help to overcome the challenges by ensuring uniform seed germination, and better seedling stand establishment. To examine the effectiveness of sodium selenite, sodium selenate, and zinc oxide nanoparticles (ZnO-NPs) as priming agents for DSR seeds, a controlled pot experiment followed by a field experiment over two consecutive years was conducted on a sandy clay loam soil (Inceptisol) in West Bengal, India. Priming with combinations of all priming agents had advantages over the hydro-priming treatment (control). All the combinations resulted in the early emergence of seedlings with improved vigour. In the field experiment, the combinations of all priming agents increased the plant chlorophyll, phenol and protein contents, leaf area index and duration, crop growth rate, uptake of nutrients $(\mathrm{N}, \mathrm{P}, \mathrm{K}, \mathrm{B}, \mathrm{Zn}$ and $\mathrm{Si}$ ) and yield of DSR over the control. Our findings suggest that seed priming with the combination of ZnO-NPs, Na-selenite, and selenate could be a viable option for the sustainable intensification of DSR.

\section{Introduction}

Direct-seeded rice (DSR), could potentially be a viable alternative to traditional puddledtransplanted rice (PTR) due to less labour requirement, increased resource (water, nutrient, energy, etc) use efficiency and higher returns (Chakraborty et al., 2017; Wang et al., 2017) in rice-growing regions of the world. Direct seeding can be achieved by sowing on the dry soil either mechanically or manually (Dry DSR), or wet soil through broadcasting (Wet DSR), or 
51 in standing water through broadcasting (Water DSR) ${ }^{1,3}$. Dry DSR could be more advantageous over the other two methods ${ }^{4,5}$ due to less time required for sowing, which economizes time and labour, and the water is saved, which otherwise is essential for wetseeding. Though PTR is the main rice transplanted system in Asia, DSR has also been gaining popularity (Timsina and Connor, 2001; Mahajan et al., 2012). For example, in China, DSR covers $28 \%$ of the total rice area ${ }^{6}$, while in Sri Lanka and Malasia, areas under DSR were $>93 \%(1.03 \mathrm{M} \mathrm{ha})$ and $95 \%\left(0.67 \mathrm{M}\right.$ ha) respectively of their respective total rice area ${ }^{7}$. In the Indian Punjab alone, DSR was adopted in $0.601 \mathrm{M}$ ha during $2021^{8}$.

Poor germination and seedling stand establishment were identified as major factors for the low productivity of DSR in South Asia ${ }^{6,9-11}$. Often in DSR when seeds are sown directly in the field, plants are exposed to multiple environmental stresses particularly during emergence and early development ${ }^{12-14}$. These stresses depress the kinetics of many physiological and metabolic processes ${ }^{15}$, generate a large number of reactive oxygen species (ROS) in plant's cells that trigger lipid peroxidation in membranes ${ }^{16-18}$. These are followed by damage to biomolecules including proteins, carbohydrates and DNA ${ }^{17,19}$, and reduce respiration rate and energy supply to growing plant tissue ${ }^{20}$. All these processes affect sequentially the germination and seedling establishment, plant stand, growth and resource utilisation, and ultimately the yield of DSR.

While the conventional breeding approach is time-consuming, genetic engineering is highly controversial albeit with its high potential benefits ${ }^{21}$. A large number of abiotic stresstolerant rice genes have been characterized during the last three decades which is being further exploited for varietal development with higher productivity in rice ${ }^{22,23}$. Seed priming has proven utility in optimising seed vigour and plant physiological processes, which makes the plant ready to face multiple probable stresses in the field more efficiently ${ }^{24-26}$. Several 
successful priming agents have been reported in the literature ranging from salts, polyamines, hormones, compatible solutes, and aqueous plant extracts (Farooq et al., 2009).

Zinc ( $\mathrm{Zn})$, an essential micronutrient, is the only metal that forms a part of the six different classes of enzymes ${ }^{28}$. It is closely involved in many biochemical and physiological processes ${ }^{29}$. Seed priming with $\mathrm{Zn}$ has shown positive effects on seed vigour, germination, early seedling growth and biomass production, photosynthetic efficiency, and in the contents of sugar, total nitrogen, protein and micronutrients in many crops (Faizan et al., 2018; Moghaddasi et al., 2017; Zhang et al., 2018). In the recent past, biologically synthesised ZnO-NPs with their enhanced physical and biochemical characteristics and low environmental toxicity showed their efficacy as priming agents ${ }^{36,37}$. Uniformity in seedling emergence and improved growth of rice plants using $\mathrm{ZnO}-\mathrm{NPs}$ as priming agent was reported with higher production of antioxidant enzymes against ROS damage ${ }^{38}$.

In plants, selenium (Se) as a constituent of selenoproteins, has been reported to enhance starch and ATP synthesis ${ }^{39}$, regulate water status, prevent chlorophyll loss during drought ${ }^{40,41}$, and delay senescence ${ }^{42}$. In addition, it regulates redox reactions ${ }^{43,44}$ and rROS concentration, and consequently lipid peroxidation ${ }^{45}$. Priming with sodium selenite has been shown to trigger germination in rice ${ }^{46}$. Subsequent studies reported the efficacy of rice seed priming with sodium selenate (Du et al., 2019) and selenite-selenate combination ${ }^{48}$ with their contributions to the assimilation and storage pathway respectively. Oxyanions of Se can promote the adsorption of $\mathrm{Zn}$ and enhance their bioavailability within the plant system by synergy ${ }^{49,50}$. To our knowledge, there is no literature on the combined application of zinc or nano-zinc with Se as seed priming agents on germination and seedling establishment and growth and yield of DSR.

In response to above gaps, We hypothesized that (1) the (synergistic) effect of $\mathrm{ZnO}$ NPs and Se as seed priming agents in DSR cultivation influences germination, and the 
emergence of healthy and robust seedlings capable of mitigating environmental stresses; and

101 (2) the sysnergistic effect could result in higher DSR yield compared to that without the priming. To test these hypotheses, a controlled pot experiment and a field experiment was undertaken with different treatments of $\mathrm{ZnO}-\mathrm{NPs}$, sodium selenate, and sodium selenite 104 single or in combination as priming agents in DSR.

\section{Materials and methods}

107

Experimental site. A pot experiment (examined for seed vigour) was conducted followed by a field experimentation (examined for plant growth traits and yield) in each year (2019 and 110 2020) on DSR at Central Research Farm of Bidhan Chandra Krishi Viswavidyalaya, West 111 Bengal, India $\left(23^{\circ} 5.3^{\prime} \mathrm{N}, 8^{\circ} 5.3^{\prime} \mathrm{E}\right.$; subtropical; $9.75 \mathrm{~m}$ amsl). The soil was sandy clay loam (sand $64.8 \%$, silt $10.4 \%$ and clay $24.8 \%$ ) with a $\mathrm{pH}$ of 7.3 and $\mathrm{EC}$ of $0.296 \mathrm{dSm}^{-1}{ }^{51}$. Initial soil properties of study site were: $11.2 \mathrm{~g} \mathrm{~kg}^{-1}$ oxidizable organic carbon (Walkley and Black, 1934), $315 \mathrm{~kg} \mathrm{ha}^{-1}$ available $\mathrm{N}^{53}, 41.6 \mathrm{~kg} \mathrm{ha}^{-1}$ available $\mathrm{P}^{54}$, and $156.4 \mathrm{~kg} \mathrm{ha}^{-1}$ available $\mathrm{K}^{55}$. The climate is tropical moist sub-humid, with hot summer, and moderately cold winter. 116 Average maximum and minimum temperatures ranged as $25-36{ }^{0} \mathrm{C}$ in summer and $10-25{ }^{0} \mathrm{C}$ 117 in winter (Supplementary Figure S1).

118 Experimental treatments. Eight treatment combinations of $\mathrm{ZnO}-\mathrm{NPs}$ and Se were selected: $119 \mathrm{~T}_{1}$ : Hydropriming with distilled water (Control); $\mathrm{T}_{2}$ : Sodium selenite, $\mathrm{Na}_{2} \mathrm{SeO}_{3} @ 50 \mu \mathrm{mol}$ 120 (as $\mathrm{Na}_{2} \mathrm{SeO}_{3}$; Sigma-Aldrich USA); $\mathrm{T}_{3}$ : Sodium selenate, $\mathrm{Na}_{2} \mathrm{SeO}_{4}$ @50 $\mu$ mol (as $\mathrm{Na}_{2} \mathrm{SeO}_{4}$;Sigma-Aldrich USA); $\mathrm{T}_{4}$ : Sodium selenite @ $50 \mu \mathrm{mol}+$ Sodium selenate @ 50 $\mu$ mol; T5: ZnO-NPs@ $10 \mu \mathrm{mol}$ (IFFCO; Tarafder et al., 2014); T6: ZnO-NPs @ $10 \mu \mathrm{mol}+$ Sodium selenite @50 $\mu \mathrm{mol} ; \mathrm{T}_{7}$ : ZnO-NPs @ $10 \mu \mathrm{mol}+$ Sodium selenate @ $50 \mu \mathrm{mol}$; and T8: ZnO-NPs@ $10 \mu \mathrm{mol}+$ Sodium selenite @ $50 \mu \mathrm{mol}+$ Sodium selenate @ $50 \mu \mathrm{mol}]$. Indica 
inbred semi-dwarf type medium slender grain rice variety Ajit IET $22066{ }^{56}$ was used in both pot and field experiments.

Pot experiment. The pot experiment was conducted in a completely randomized design under factorial arrangements with three replications. A $25 \mathrm{~g}$ of seeds were placed in a $200 \mathrm{ml}$ conical flask containing $125 \mathrm{ml}$ initiator solution as per the treatment $\left(\mathrm{ZnO}-\mathrm{NPs}, \mathrm{Na}_{2} \mathrm{SeO}_{3}\right.$, $\mathrm{Na}_{2} \mathrm{SeO}_{4}$ ), and aerated distilled water for the control and seeds were kept for imbibition or 24 h. The flasks were placed in an incubator [darkness, $27 \pm 3{ }^{\circ} \mathrm{C}$ and $80 \%$ relative humidity] and were shaken once every $6 \mathrm{~h}$. After priming, the seeds were filtered, placed in distilled water for 20 minutes and rinsed five times with ultrapure water. Autoclaved glass Petri dishes were lined with double layers of filter paper and were placed on a laboratory bench for air drying for a period of $24 \mathrm{~h}$. Thereafter, $10 \mathrm{ml}$ sterile water was aseptically pipetted into and 100 seeds were placed in each petri-dish. Each seed soaking treatment was performed in triplicate petri-dishes, which were kept inside an incubator at $26 \pm 0.5^{\circ} \mathrm{C}$ under aseptic condition.

Seeds were sown in plastic pots $(15.6 \mathrm{~cm}$ height, $18.2 \mathrm{~cm}$ top diameter and $12.5 \mathrm{~cm}$ lower diameter), which were filled with air-dried and well-mixed field soil (2000 g) collected from the study site. Seeds were sown uniformly in each pot with soil moisture at field 144 capacity $(-0.03 \mathrm{MPa})$. Pots were placed in a screen house under the natural condition with a 145 14/10 $\mathrm{h}$ light/dark photoperiod and uniformly irrigated with distilled water as per the 146 requirement to avoid water deficit. The seed emergence was counted daily according to the 147 Association of Official Seed Analysts (AOSA) ${ }^{57}$ until a constant count was achieved. A seed was taken as emerged when the hypocotyl length was $\geq 2 \mathrm{~mm}$. Time taken to $50 \%$ emergence of seedlings ( $\left.\mathrm{E}_{50}\right)$ was calculated according to the modified formula of Farooq et al. (2005): 


$$
\mathrm{E}_{50}=\mathrm{ti}+\frac{\left(\frac{\mathrm{N}}{2}-\mathrm{ni}\right)(\mathrm{tj}-\mathrm{ti})}{(\mathrm{nj}-\mathrm{ni})}
$$

151 where $\mathrm{N}$ is the final number of emerged seeds; ni and nj are the cumulative number of seeds

152 emerged by adjacent counts at times ti and $\mathrm{tj}$ where $\mathrm{ni}<\mathrm{N} / 2<\mathrm{nj}$. Mean emergence time 153 (MET), an indicator of relative emergence of seedling in a day was calculated according to 154 Ellis and Roberts (1981):

$$
\operatorname{MET}=\frac{\Sigma(\mathrm{D} * \mathrm{n})}{\Sigma \mathrm{n}}
$$

where $\mathrm{n}$ is the number of new emerging seeds on day $\mathrm{D}$ (number of days from the beginning of emergence). The emergence index (EI), which is a measure for percentage and rate of germination, was calculated as described by AOSA (1990):

$$
\mathrm{EI}=\frac{\text { Number: of emerged seeds }}{\text { Days of the first count }}+\cdots+\frac{\text { Number of emerged seeds }}{\text { Days of the final count }}
$$

Vigour index (VI) was calculated after Wang et al. (2018).

$$
\mathrm{VI}=\mathrm{Sd} \times \sum\left(\frac{\mathrm{Gt}}{\mathrm{t}}\right)
$$

where Sd is the seedling dry weight at the end of the test period (7 days), Gt is the number of germinated seeds on day $\mathrm{t}$ from the beginning of the test.

164 Root and shoot lengths were measured on 18 days after sowing (DAS) from each treatment. 165 For these, five randomly selected seedlings were oven-dried at $70{ }^{\circ} \mathrm{C}$ for $48 \mathrm{~h}$ to get the dry biomass of root and shoot, and both the components were summed up to record the total seedling biomass.

Field experiment. The experiment was laid out in a factorial randomized complete block design with three replications. Fields were prepared by cultivating twice using a disc harrow 171 (Unison Exports, Ludhiana, Punjab, India), followed by leveling with a wooden board. Pregerminated primed seeds were sown manually by a single-row planter having an inclined plate mechanism @ $25 \mathrm{~kg} \mathrm{ha}^{-1}$ at $20 \mathrm{~cm}$ row-to-row spacing. The field was surface-irrigated immediately after sowing. Soil water potential was monitored with tensiometers installed at 
$17520 \mathrm{~cm}$ depth, and the field was irrigated at $-30 \mathrm{kPa}$ potential. Fertilizers were applied as per 176 soil test-based recommendations ${ }^{62}$ with a basal application of $\mathrm{N}$ at $25 \mathrm{~kg} \mathrm{ha}^{-1}, \mathrm{P}_{2} \mathrm{O}_{5}$ at $50 \mathrm{~kg}$

$177 \mathrm{ha}^{-1}, \mathrm{~K}_{2} \mathrm{O}$ at $50 \mathrm{~kg} \mathrm{ha}^{-1}$, and $\mathrm{ZnSO}_{4}$ at $5 \mathrm{~kg} \mathrm{ha}^{-1}$ as urea, single super phosphate and muriate 178 of potash, respectively. Additionally, $75 \mathrm{~kg} \mathrm{~N} \mathrm{ha}^{-1}$ in the form of urea and ammonium 179 sulphate (AS) was applied in two splits: one half at the active tillering stage (urea and AS in 180 equal proportion) and the other half at the panicle initiation stage (only through AS). Weeds were controlled by a pre-emergence herbicide [Pendimethalin @0.75 kg a.i. ha ${ }^{-1}$ ] at 2 DAS, followed by a post-emergence herbicide [Bispyribac-sodium @ $25 \mathrm{~g}$ a.i. ha ${ }^{-1}$ ] at 20 DAS. Weeds that escaped these treatments were removed manually at 42 DAS. Chloropyriphos @50 g a.i. ha $\left.{ }^{-1}\right]$ and propiconazole @62.5 g a.i. ha ${ }^{-1}$ ] were used to control insects and diseases, respectively. Irrigation was withdrawn 15 days before harvest. All agronomic management practices were the same in both years. Grains were harvested at $15-18 \%$ grain moisture content.

Growth traits analysis. Plants were collected from 1-m length within a row in each plot at 190 initiation of tillering (14 DAS), panicle initiation (42 DAS), 50\% flowering stage (70 DAS) and physiological maturity (108 DAS) to determine aboveground biomass and green leaf area index (LAI). Green leaves were separated and area was measured with a leaf area meter (LI3100, LI-COR, Lincoln, Nebraska, USA). The LAI was expressed as leaf area per unit of area sampled for each plot. Dry weights of each plant part were determined after oven-drying at $80^{\circ} \mathrm{C}$ to calculate crop growth rate (CGR), net biomass assimilation rate (NAR), and leaf area duration (LAD) ${ }^{63,64}$ for vegetative (up to 41 DAS), reproductive (42-69 DAS) and grain

197 filling (70-108 DAS) stage using following equations:

198

$$
\begin{aligned}
& \mathrm{CGR}=\frac{\mathrm{W}_{2}-\mathrm{W}_{1}}{\mathrm{t}_{2}-\mathrm{t}_{1}} \\
& \mathrm{NAR}=\frac{\mathrm{W}_{2}-\mathrm{W}_{1}}{\mathrm{t}_{2}-\mathrm{t}_{1}} \times \frac{\log _{\mathrm{e}} \mathrm{L}_{2}-\log _{\mathrm{e}} \mathrm{L}_{1}}{\mathrm{~L}_{2}-\mathrm{L}_{1}}
\end{aligned}
$$




$$
\mathrm{LAD}=\frac{\mathrm{L}_{2}+\mathrm{L}_{1}}{2} \times\left(\mathrm{t}_{2}-\mathrm{t}_{1}\right)
$$

where $\mathrm{W}_{1}$ and $\mathrm{W}_{2}$ were dry weights of aerial plant parts per unit land area at time $\mathrm{t}_{1}$ and $\mathrm{t}_{2}$,

202 203

204

205

206

207

208

209

210

211

212

213

214

215

216

217 Yield and yield components. Grain and straw yields were determined at physiological 218 1000-grain weight ${ }^{73}$. 
224 Statistical analyses. All data from pot and field experiments were analysed using a mixed 225 ANOVA model in SAS, considering year and treatment, and their two-way interactions as

226

227

factors. Treatment adjusted means were separated by using HSD Tukey multiple range test at $5 \%$ level of significance (Wang et al., 2017). The coefficient of determination $\left(\mathrm{R}^{2}\right)$ and correlogram were calculated to assess the degree of association between two variables using the JMP Pro 16.

\section{Results}

\section{Pot Experiment}

Seed germination emergence and vigour, and enzymatic and biochemical activities. Seed priming improved gemination and vigour attributes, although year-to-year differences were evident (Supplementary Table S1). Priming with either Se or ZnO-NPs alone or in combination reduced the time to start of emergence (TSE), time to reach $50 \%$ germination $\left(\mathrm{E}_{50}\right)$ and mean emergence time (MET) compared to the control, while EI and VI parameters improved over the control (Table 1). Percent reduction in TSE (43.3), MET (25.5) and E50 (30.9), and percent increase in EI (66.4) and VI (112.3) were greater with the combined application of ZnO-NPs, selenate and selenite. Even selenite and ZnO-NPs combination favoured the germination, as evidenced in germination parameters except for the TSE.

A minimum leachate conductivity of seeds was recorded in the combination of all three priming agents (Supplementary Fig. S2). Selenate was more effective in increasing antioxidant enzyme activities compared to selenate, and the priming through the combination of selenite, selenate $\mathrm{ZnO}-\mathrm{NPs}$ resulted in improved biochemical activities in DSR seeds (Supplementary Table S2). 
250 Chlorophyll, phenol and soluble protein content in rice seedling. Total chlorophyll,

251 phenol and soluble protein contents in rice seedlings increased through priming of seeds over 252 the control (Table 2). The combination of selenite, selenate and ZnO-NPs recorded the 253 highest total chlorophyll $\left(5.39 \mathrm{mg} \mathrm{g}^{-1}\right)$, phenol $\left(0.58 \mathrm{mg} \mathrm{g}^{-1}\right)$ and soluble protein $\left(0.37 \mathrm{mg} \mathrm{g}^{-1}\right)$ contents, although comparable with $\mathrm{ZnO}-\mathrm{NPs}+$ selenate treatment (chlorophyll, phenol and 255 soluble protein were 5.27, 0.57 and $0.35 \mathrm{mg} \mathrm{g}^{-1}$ ).

256

257

Plant growth analysis. All priming treatments either singly or in combination, affected chlorophyll, phenolics and soluble protein contents of seedlings, growth behaviour, nutrient uptake of plants and crop yields at harvest (Supplementary Table S3). Year-to-year variation was also noticed in parameters with a few exceptions (soluble proteins, cop growth rate at vegetative stage and net assimilation rate at ripening stage). However, year-treatment interactions were mostly non-significant. The impact of priming of seeds is manifest in plant LAI (Fig. 1). The highest LAI was observed with ZnO-NPs-sodium selenite-sodium selenate combination in all stages - 1.66 (early tillering), 3.50 (panicle initiation), 5.21 (early grain filling) and 3.18 (physiological maturity); values were $81 \%, 93 \% 56 \%$, and $55 \%$ higher, respectively over the control.

Seed priming impacted other physiological parameters like leaf area duration (LAD) (Fig. 2), crop growth rate (CGR) (Fig. 3) and net biomass assimilation rate (NAR) (Fig. 4) during early tillering to panicle initiation stage (14-42 DAS), panicle initiation to completion of pollination (42-70 DAS) and entire grain filling stage (72 DAS-108 DAS).

271 The impact of selenate on LAI and LAD was always greater than that of selenite, and the 272 combined selenite-selenate was even more effective. A similar trend was recorded for CGR 273 except during 42-70 DAS where selenate alone and with selenite had a comparable effect. 
274 Seed priming by ZnO-NPs alone or with selenite did not bring a change in either LAI or 275 LAD, although the effect was greater with selenate and was the best when combined with

276

277

278

279

280

281

282

283

284

285

286

287

288

289

290

291

292

293

294

295

296

297

298 selenite and selenate. Likewise, a combination of ZnO-NPs with selenite and selenate together had the best priming effect on CGR. Overall, improved LAI and LAD with seed priming contributed $9-55 \%$ higher crop growth rate and 34-109\% higher net assimilation rate in comparison to control. The NAR showed a mixed trend, with all treatments behaving similarly in 14-42 DAS although all three agents in combination showed less NAR compared to single ZnO-NPs. During 42-70 DAS, ZnO-NPs alone or in combination with both selenite and selenate recorded lower NAR, however, all treatments had a similar effect during 70-108, but higher than the control.

Nutrient uptake by plants. Nutrient uptake $\left(153 \mathrm{~kg} \mathrm{~N} \mathrm{ha}^{-1}, 48.6 \mathrm{~kg} \mathrm{P} \mathrm{ha}^{-1}, 78.7 \mathrm{~kg} \mathrm{~K} \mathrm{ha}^{-1}\right.$, $24.6 \mathrm{~kg} \mathrm{~B} \mathrm{ha}^{-1}, 321 \mathrm{~g} \mathrm{Zn} \mathrm{ha}^{-1}$, and $188 \mathrm{~kg} \mathrm{Si} \mathrm{ha}^{-1}$ ) was the highest with the combined use of selenite, selenate and $\mathrm{ZnO}-\mathrm{NPs}$ as priming agents (Table 3). The efficacy of selenate was greater in harnessing soil nutrients compared to either selenite or ZnO-NPs.

Yield attributes, grain and straw yields. Seed priming improved the grain yield in DSR due to an increase in panicle density, grains per panicle and grain-filling (Table 4). Considering seed-priming effects, grain yield ranged from 3.91 $\mathrm{ha}^{-1}$ in the second year with hydropriming treatment to $6.15 \mathrm{t} \mathrm{ha}^{-1}$ in the first year with combined application of $\mathrm{ZnO}-\mathrm{NPs}$, selenite and selenate. Yields were significantly lower in YII than in Y1. Straw yields followed a similar pattern. Application of selenite and selenate with $\mathrm{ZnO}-\mathrm{NPs}$ registered a $25.9 \%$ higher grain yield over the control, compared to 11-13\% increase with application of ZnO-NPs with either selenite or selenate. Yield gains in treatment with the combination of all three priming agents could be ascribed to $12.0,47.1$ and $27.8 \%$ increases in panicles, filled grains per panicle, and 
grain filling percentage respectively over the control. Combined application of ZnO-NPS and selenite or ZnO-NPS and selenate as priming agents also resulted in 7.6-8.7, 32.8-32.9, 22.223.6\% higher panicles, filled grains per panicle and grain filling efficiency respectively over control. However, sole use of selenite, selenate and $\mathrm{ZnO}-\mathrm{NPs}$ also contributed 5.5, 6.2 and $5.0 \%$ higher grain yield over hydro priming.

Discussion

306

Seed priming by zinc oxide nanoparticles, Na-selenite and selenate either singly or in combinations, facilitated speedy germination and early vigour of seedlings in direct-seeded rice. Priming reduced time to start of emergence as well as time to reach $50 \%$ germination. Primed seeds have shown low MET, a measure of the rate and time-spread of germination ${ }^{75}$, and enhanced seed emergence and vigour indices. There were increases in enzymatic antioxidant functions in seeds necessary to reduce the production of degenerative radicals and

313 therefore, seeds would likely be protected from damage during environmental (growing condition) stress. Consequently, lengths of seedlings (root and shoot, on 18 DAS) largely increased(Supplementary Figure S3). All enzyme activities were positively correlated with seed vigour indices and the seedling growth following seed priming (Supplementary Figure S4). Sodium selenate had a clear advantage over sodium selenite when combined with zinc oxide nanoparticles. However, the combination of all three had the maximum impact. water and nutrient uptake by plants and to provide competitiveness against biotic and abiotic stresses $^{3,76}$. Due to chemical priming of seeds, plants used soil nutrients (N, P, K, B, Zn, Si) more efficiently resulting in higher density of grains per panicle, and finally leading to higher yields in DSR compared to grain imbibition with pure water. Selenate improved rice seedling 
germination and growth, and soluble carbohydrate and protein contents in plants compared to hydropriming ${ }^{47}$. The $\mathrm{ZnO}$ nano particles had similar positive effects on seed germination, seedling growth and dry biomass in rice ${ }^{77}$ and wheat ${ }^{78}$. The $\mathrm{Zn}$ content in primed rice seeds was several times higher compared to hydropriming ${ }^{77}$. The success with $\mathrm{Zn}$ nanoparticles may encourage future research on other micronutrients as priming agents ${ }^{77}$.

Chlorophyll is associated with photosynthetic activity, and hence it is an indicator of vegetative growth and vigour of a plant. Phenolics are secondary metabolites, which promote the adaptation capability of plants during stress. Soluble proteins have diverse roles in promoting growth including osmoregulation in plants under adverse growth environments ${ }^{79}$.

333 A combination of $\mathrm{ZnO}$ nanoparticles, Na-selenite and Na-selenate priming had the best impact on chlorophyll, phenol and soluble protein contents in rice seedlings, resulting in higher leaf area index and duration, and crop growth rate. A combination of sodium selenite and selenate was more effective in promoting the growth of plants (higher leaf area index, leaf area duration and crop growth rate) compared to when these were used singly or even when seeds were primed by nano-zinc formulation only. However, the combination of both selenite and selenate with nano-zinc induced the largest changes in growth parameters. These led to higher yield-contributing factors such as grain-filling efficiency, test weight and

341 harvest index. The highest DSR yield was, however, obtained with a combination of the three seed priming materials.

Our results established that combinations of Na-selenite, Na-selenate and zinc oxide nanoparticles were potential seed invigoration techniques, and the best results were obtained with all three chemicals in combination. Responses differed between years; however, positive impacts on the field crop were established. Seeds with high vigour are proxy of sustainable

347 productivity, especially under adverse conditions, although suitable field studies are lacking.

348 Uniform seed emergence, crop stand and establishment are major challenges for successful 
349 DSR cultivation ${ }^{10}$. Direct-seeded rice often fails to emerge uniformly due to uneven land 350 preparation leading to imprecise water management, and therefore weed infestations take

351 place heavily ${ }^{80}$. On the other side, low oxygen availability in rainfed lowlands owing again 352 to poor water management, seeds fail to germinate ${ }^{81}$. Priming of DSR seeds can give 353 necessary vigour to the plants to sustain better under unfavourable growing conditions. The 354 modified traits in seeds effectively translate into early seedling vigour and agility in growing 355 plants, which is perfectly tuned with increased productivity in the field-grown rice. This 356 small intervention (seed priming) will support the rice growers to embrace direct seeding of 357 rice as a replacement of water- and labour-intensive puddled transplanted rice. Farmers will 358 also get an opportunity to widen the window of sowing of wheat following rice in large tracts 359 of rice-wheat rotation in Indo-Gangetic Plains of South Asia.

360

\section{Conclusion}

362

363 Both $\mathrm{Zn}$ and Se have found their effectiveness in seed-priming. It was observed that zinc 364 oxide nanoparticles with both forms of Se were synergistic in their action, and provided 365 further benefits compared to their single applications. The impact was evaluated in directseeded rice production often exposed to adverse growing conditions and therefore, not realizing full potential productivity. Priming of seeds with zinc oxide-sodium selenite selenate combination resulted in an early emergence due to more seed vigour, and extended to the improvement in plant growth and productivity in DSR in the field. This has implications in the vast rice-growing areas in South Asia in general, and to the rice-wheat system of Indo-Gangetic Plains of South Asia in particular.

372 
The corresponding author acknowledges the fellowship for the first author from a research grant of the Department of Higher Education, Science \& Technology and Biotechnology, Government of West

\section{References}

379 1. Chakraborty, D. et al. A global analysis of alternative tillage and crop establishment practices for economically and environmentally efficient rice production. Sci. Rep. 7, 1-11 (2017).

2. Wang, W. et al. The possibility of replacing puddled transplanted flooded rice with dry seeded rice in central China: A review. F. Crop. Res. 214, 310-320 (2017).

3. Mahender, A., Anandan, A. \& Pradhan, S. K. Early seedling vigour, an imperative trait for direct-seeded rice: an overview on physio-morphological parameters and molecular markers. Planta 241, 1027-1050 (2015).

4. Chauhan, B. S. Weed Ecology and Weed Management Strategies for Dry-Seeded Rice in Asia. Weed Technol. 26, 1-13 (2012).

5. Joshi, E. et al. Management of direct seeded rice for enhanced resource - use efficiency. Plant Knowl. J. 2, 119-134 (2013).

6. Liu, H. et al. Progress and constraints of dry direct-seeded rice in China. J. Food, Agric. Environ. 12, 465-472 (2014).

7. Kumar, V. \& Ladha, J. K. Direct Seeding of Rice. Recent Developments and Future

8. Kamal, N. Direct seeded rice area up in Punjab. The Times of India (2021).

9. Qi, X. et al. Grain yield and apparent $\mathrm{N}$ recovery efficiency of dry direct-seeded rice under different $\mathrm{N}$ treatments aimed to reduce soil ammonia volatilization. F. Crop. Res. 134, 138-143 (2012).

10. Farooq, M. et al. Soil \& Tillage Research Rice direct seeding : Experiences, challenges and opportunities. Soil Tillage Res. 111, 87-98 (2011).

11. Singh, Y., Singh, G., Johnson, D. \& Mortimer, M. Changing from transplanted rice to direct seeding in the rice-wheat cropping system in India. in Rice is Life: Scientific Perspectives for the 21 st Century, Tsukuba, Japan: Proceedings of the World Rice Research Conference, 4-7 November 2004, 198-201 (2004).

12. Ray, S., Vijayan, J. \& Sarkar, R. K. Germination stage oxygen deficiency (GSOD): An emerging stress in the era of changing trends in climate and rice cultivation practice. Front. Plant Sci. 7, 1-4 (2016).

13. Kaur, J. \& Singh, A. Direct Seeded Rice: Prospects, Problems/Constraints and Researchable Issues in India. Curr. Agric. Res. J. 5, 13-32 (2017). 
14. Rao, A., Wani, S., Ramesha, M. \& Ladha, J. Rice Production Systems. in Rice Production Worldwide (eds. B., C., K., J. \& G., M.) 185-205 (Springer, Cham., 2017). doi:10.1007/978-3-319-47516-5.

15. Ruelland, E., Vaultier, M. N., Zachowski, A. \& Hurry, V. Chapter 2 Cold Signalling and Cold Acclimation in Plants. Advances in Botanical Research vol. 49 (Elesvier Ltd, 2009).

16. Guo, Z., Ou, W., Lu, S. \& Zhong, Q. Differential responses of antioxidative system to chilling and drought in four rice cultivars differing in sensitivity. Plant Physiol. Biochem. 44, 828-836 (2006).

17. Gill, S. S. \& Tuteja, N. Reactive oxygen species and antioxidant machinery in abiotic stress tolerance in crop plants. Plant Physiol. Biochem. 48, 909-930 (2010).

18. Shu, D. F., Wang, L. Y., Duan, M., Deng, Y. S. \& Meng, Q. W. Antisense-mediated depletion of tomato chloroplast glutathione reductase enhances susceptibility to chilling stress. Plant Physiol. Biochem. 49, 1228-1237 (2011).

19. Zhang, M., Jin, Z. Q., Zhao, J., Zhang, G. \& Wu, F. Physiological and biochemical responses to drought stress in cultivated and Tibetan wild barley. Plant Growth Regul. 75, 567-574 (2015).

20. Taylor, N. L., Day, D. A. \& Millar, A. H. Environmental stress causes oxidative damage to plant mitochondria leading to inhibition of glycine decarboxylase. J. Biol. Chem. 277, 42663-42668 (2002).

21. Ahmad, N. \& Mukhtar, Z. Genetic manipulations in crops: Challenges and opportunities. Genomics 109, 494-505 (2017).

22. Pareek, A., Sopory, S. K., Bohnert, H. J. \& Govindjee. Abiotic stress adaptation in plants: Physiological, molecular and genomic foundation. Abiotic Stress Adapt. Plants Physiol. Mol. Genomic Found. 1-526 (2010) doi:10.1007/978-90-481-3112-9.

23. Sevanthi, A. M., Prakash, C. \& Shanmugavadivel, P. S. Recent progress in rice varietal development for abiotic stress tolerance. Advances in Rice Research for Abiotic Stress Tolerance (Elsevier Inc., 2019). doi:10.1016/B978-0-12-8143322.00003-4.

24. Bałabusta, M., Szafrańska, K. \& Posmyk, M. M. Exogenous melatonin improves antioxidant defense in cucumber seeds (Cucumis sativus L.) germinated under chilling stress. Front. Plant Sci. 7, 1-12 (2016).

25. Espanany, A., Fallah, S. \& Tadayyon, A. Seed priming improves seed germination and reduces oxidative stress in black cumin (Nigella sativa) in presence of cadmium. Ind. Crops Prod. 79, 195-204 (2016).

26. Acharya, P., Jayaprakasha, G. K., Crosby, K. M., Jifon, J. L. \& Patil, B. S. Nanoparticle-Mediated Seed Priming Improves Germination, Growth, Yield, and Quality of Watermelons (Citrullus lanatus) at multi-locations in Texas. Sci. Rep. 10, 116 (2020).

27. Farooq M, Basra S M A, Wahid A, Khaliq A, K. N. Rice seed invigoration: a review. in Organic farming, pest control and remediation of soil pollutants: sustainable 
agricultural reviews (ed. Lichtfouse, E.) 137-175 (Springer Science, 2009). doi:10.1007/978-1-4020-9654-9.

28. Broadley, M. R., White, P. J., Hammond, J. P., Zelko, I. \& Lux, A. Zinc in plants. New Phytol. 173, 677-702 (2007).

29. Li, Y. et al. Spatial-temporal analysis of zinc homeostasis reveals the response mechanisms to acute zinc deficiency in Sorghum bicolor. New Phytol. 200, 1102-1115 (2013).

30. Rehman, A., Farooq, M., Ahmad, R. \& Basra, S. M. A. Seed priming with zinc improves the germination and early seedling growth of wheat. Seed Sci. Technol. 43, 262-268 (2015).

31. Harris, D., Rashid, A., Miraj, G., Arif, M. \& Yunas, M. 'On-farm' seed priming with zinc in chickpea and wheat in Pakistan (Plant and Soil DOI: 10.1007/s11104-0079465-4). Plant Soil 306, 11 (2008).

32. Dhoke, S. K., Mahajan, P. \& Khanna, A. S. Effect of nano-ZnO particle suspension on growth of mung (Vigna radiata) and gram (Cicer arietinum) seedlings using plant agar method. J. Nanotechnol. 2011, (2011).

33. Moghaddasi, S. et al. Effects of coated and non-coated $\mathrm{ZnO}$ nano particles on cucumber seedlings grown in gel chamber. Arch. Agron. Soil Sci. 63, 1108-1120 (2017).

34. Faizan, M., Faraz, A., Yusuf, M., Khan, S. T. \& Hayat, S. Zinc oxide nanoparticlemediated changes in photosynthetic efficiency and antioxidant system of tomato plants. Photosynthetica 56, 678-686 (2018).

35. Zhang, T. et al. Using Synchrotron-Based Approaches to Examine the Foliar Application of $\mathrm{ZnSO} 4$ and $\mathrm{ZnO}$ Nanoparticles for Field-Grown Winter Wheat. $J$. Agric. Food Chem. 66, 2572-2579 (2018).

36. Wang, X., Ding, Y., Summers, C. J. \& Wang, Z. L. Z. Large-Scale Synthesis of SixNanometer-Wide ZnO Nanobelts Xudong. J. Phys. Chem. 108, 8773-8777 (2004).

37. Sharifi, R. Effect of seed priming and foliar application with micronutrients on quality of forage corn (Zea mays). Environ. Exp. Biol. 14, 151-156 (2016).

38. Upadhyaya, H. et al. Physiological impact of Zinc nanoparticle on germination of rice (Oryza sativa L) seed. J. Plant Sci. Phytopathol. 1, 062-070 (2017).

39. Turakainen, M., Hartikainen, H., Ekholm, P. \& Seppänen, M. M. Distribution of selenium in different biochemical fractions and raw darkening degree of potato (Solanum tuberosum L.) tubers supplemented with selenate. J. Agric. Food Chem. 54, 8617-8622 (2006).

40. Kaklewski, K., Nowak, J. \& Ligocki, M. Effects of selenium content in green parts of plants on the amount of ATP and ascorbate-glutathione cycle enzyme activity at various growth stages of wheat and oilseed rape. J. Plant Physiol. 165, 1011-1022 (2008).

41. Kuznetsov, V. \& Kuznetsov, V. Selenium regulates the water status of plants exposed 
to drought. Dokl. Biol. Sci. 390, 266-268 (2003).

492

493

494

495

496

497

498

499

500

501

502

503

504

505

506

507

508

509

510

511

512

513

514

515

516

517

518

519

520

521

522

523

524

525

526

527

528

529

42. Djanaguiraman, M., Devi, D. D., Shanker, A. K., Sheeba, J. A. \& Bangarusamy, U. Selenium - An antioxidative protectant in soybean during senescence. Plant Soil 272, 77-86 (2005).

43. Kong, L., Wang, M. \& Bi, D. Selenium modulates the activities of antioxidant enzymes, osmotic homeostasis and promotes the growth of sorrel seedlings under salt stress. Plant Growth Regul. 45, 155-163 (2005).

44. Sattar, A. et al. Physiological and biochemical attributes of bread wheat (Triticum aestivum L.) seedlings are influenced by foliar application of silicon and selenium under water deficit. Acta Physiol. Plant. 41, 1-11 (2019).

45. Sieprawska, A., Kornaś, A. \& Filek, M. Involvement of selenium in protective mechanisms of plants under environmental stress conditions - Review. Acta Biol. Cracoviensia Ser. Bot. 57, 9-20 (2015).

46. Khaliq, A. et al. Seed priming with selenium: Consequences for emergence, seedling growth, and biochemical attributes of rice. Biol. Trace Elem. Res. 166, 236-244 (2015).

47. Du, B. et al. Rice seed priming with sodium selenate: Effects on germination, seedling growth, and biochemical attributes. Sci. Rep. 9, 1-9 (2019).

48. Versini, A. et al. Influence of Se concentrations and species in hydroponic cultures on Se uptake, translocation and assimilation in non-accumulator ryegrass. Plant Physiol. Biochem. 108, 372-380 (2016).

49. Kader, M., Lamb, D. T., Wang, L., Megharaj, M. \& Naidu, R. Zinc-arsenic interactions in soil: Solubility, toxicity and uptake. Chemosphere 187, 357-367 (2017).

50. Xue, M. et al. Effects of selenium combined with zinc amendment on zinc fractions and bioavailability in calcareous soil. Ecotoxicol. Environ. Saf. 190, 110082 (2020).

51. Datta, S. P., SubbaRao, A. \& Ganeshamurthy, A. N. Effect of electrolytes coupled with variable stirring on soil pH. J. Indian Soc. Soil Sci. 45, 185-187 (1997).

52. Walkley, A., Black, I. A. An examination of the degtjarff method for determining soil organic matter and a proposed modification of the chromic acid titration method. Soil Sci. 37, 29-38 (1934).

53. Subbiah, B. V. \& Asija, G. L. A rapid procedure for the determination of available nitrogen in soils. Curr. Sci. 25, 259-260 (1956).

54. Olsen, S. R. \& Sommers, L. E. Phosphorus. in Methods of Soil Analysis Part 2 Chemical and Microbiological Properties (ed. Page, A. L.) 403-430 (Olsen, S.R. and Sommers, L.E. (1982) Phosphorus. In: American Society of Agronomy, Soil Science Society of America, Madison, 1982).

55. Warncke, D. \& Brown, J. R. Potassium and other basic cations Recommended chemical soil test procedures for the North Central Region. vol. 1001 (1998).

56. Sinha, S. K., Roy, A., Satiar, S. \& Bhadra, K. K. Variety Ajit IET 22066. Indian J. 
57. Ruan, S., Xue, Q. \& Tylkowska, K. Effects of seed priming on emergence and health of rice ( Oryza sativa L.) seeds. Seed Sci. Technol. 30, 451-458 (2002).

533

534

535

536

537

538

539

540

541

542

543

544

545

546

547

548

549

550

551

552

553

554

555

556

557

558

559

560

561

562

563

564

565

566

567

58. Farooq, M., Basra, S. M. A., Ahmad, N. \& Hafeez, K. Thermal hardening: A new seed vigor enhancement tool in rice. J. Integr. Plant Biol. 47, 187-193 (2005).

59. Ellis, R. A. \& Roberts, E. H. The quantification of ageing and survival in orthodox seeds. Seed Sci. Technol. 9, 373-409 (1981).

60. Association of Official Seed Analysts (AOSA). Rules for testing seeds. J. Seed Technol. 12, 1-112 (1990). J. seed Technol. 12, 1-112 (1990).

61. Wang, X., Zheng, H. \& Tang, Q. Early harvesting improves seed vigour of hybrid rice seeds. Sci. Rep. 8, 1-7 (2018).

62. Anonymous. Soil Test-based Fertilizer Recommendations for Principal Crops and Cropping Sequences in West Bengal, Department of Agriculture, Government of West Bengal, India. (2008).

63. Weraduwage, S. M. et al. The relationship between leaf area growth and biomass accumulation in Arabidopsis thaliana. Front. Plant Sci. 6, 1-21 (2015).

64. Power, J. F., Willis, W. O., Grunes, D. L. \& Reichman, G. A. Effect of Soil Temperature, Phosphorus, and Plant Age on Growth Analysis of Barley 1 . Agron. J. 59, 231-234 (1967).

65. Randhir, R. \& Shetty, K. Developmental stimulation of total phenolics and related antioxidant activity in light- and dark-germinated corn by natural elicitors. Process Biochem. 40, 1721-1732 (2005).

66. Lichtenthaler, H. K. Chlorophylls and Carotenoids: Pigments of Photosynthetic Biomembranes. Methods Enzymol. 148, 350-382 (1987).

67. Guy, C., Haskell, D., Neven, L., Klein, P. \& Smelser, C. Hydration-state-responsive proteins link cold and drought stress in spinach. Planta 188, 265-270 (1992).

68. Jackson, M. L. Soil chemical analysis. Prentice Hall of India Pvt. Ltd., New Delhi (1973).

69. Schindler, F. V., Woodard, H. J. \& Doolittle, J. J. Plant available potassium assessment through chemical prediction methods. Commun. Soil Sci. Plant Anal. 33, 1473-1484 (2002).

70. Bingham, F. T. Boron 431 - 47 (Am. Soc. Agron.,1982). in Methods of Soil Analysis, Part 2. Chemical and Microbiological Properties (ed. Page, A. L.) vol. 9 431-447 (ASA-SSSA,Madison, USA., 1982).

71. Elliott, C. L. \& Snyder, G. H. Autoclave-Induced Digestion for the Colorimetric

72. Biswas, B. et al. Weed control in transplanted rice with post-emergence herbicides and their effects on subsequent rapeseed in Eastern India. Int. J. Pest Manag. 0, 1-13 
73. Biswas, B. et al. Integrated assessment of cropping systems in the Eastern IndoGangetic plain. F. Crop. Res. 99, 35-47 (2006).

571

572

573

574

575

576

577

578

579

580

581

582

583

584

585

586

587

588

589

590

591

592

593

594

595

596

597

598

599

600

601

602

603

604

605

606

607

74. Wang, Y. et al. Comparing the Performance of Approaches for Testing the

Homogeneity of Variance Assumption in One-Factor ANOVA Models. Educ. Psychol. Meas. 77, 305-329 (2017).

75. Bewley, J. D., Bradford, K. J., Hilhorst, H. W. M. \& Nonogaki., H. Seeds: Physiology of development, germination and dormancy. (Springer New York Heidelberg Dordrecht London, 2013).

76. Shi, Z. et al. Morphological and physiological factors contributing to early vigor in the elite rice cultivar 9 , 311. Sci. Rep. 1-15 (2020) doi:10.1038/s41598-020-71913-y.

77. Itroutwar, P. D. et al. Seaweed-Based Biogenic ZnO Nanoparticles for Improving Agro-morphological Characteristics of Rice (Oryza sativa L.). J. Plant Growth Regul. 39, 717-728 (2020).

78. Rai-Kalal, P. \& Jajoo, A. Priming with zinc oxide nanoparticles improve germination and photosynthetic performance in wheat. Plant Physiol. Biochem. 160, 341-351 (2021).

79. Sadura, I. \& Janeczko, A. Physiological and molecular mechanisms of brassinosteroidinduced tolerance to high and low temperature in plants. Biol. Plant. 62, 601-616 (2018).

80. Fukai, S. \& Wade, L. Rice. in Crop Physiology: Case Histories for Major Crops (eds. Sardas, V. \& Calderini, D.) 44-97 (Academic Press, 2021).

81. Sudhir-Yadav et al. Growing Rice in Eastern India: New Paradigms of Risk Reduction and Improving Productivity. in The Future Rice Strategy for India (eds. Mohanty, S. et al.) 221-258 (Academic Press, 2017). doi:https://doi.org/10.1016/B978-0-12-8053744.00008-7.

82. Bailly, C., Benamar, A., Corbineau, F. \& Côme, D. Changes in malondialdehyde content and in superoxide dismutase, catalase and glutathione reductase activities in sunflower seeds as related to deterioration during accelerated aging. Physiol. Plant. 97, 104-110 (1996).

83. Lee, S. S. \& Kim, J. H. Rice Activity2.Pdf. Korean J. Crop Sci. 45, 108-111 (2000).

84. Dubois, M., Gilles, K. A., Hamilton, J. K., Rebers, P. A. \& Smith, F. Colorimetric Method for Determination of Sugars and Related Substances. Anal. Chem. 28, 350 356 (1956).

85. Giannopolitis, C. N. \& Ries, S. K. Superoxide dismutases: I. Occurrence in higher plants. Plant Physiol. 59, 309-14 (1977).

86. Dhindsa, R. S., Plumb-dhindsa, P. \& Thorpe, T. A. D032_Leaf Senescence : Correlated with Increased Levels of Membrane Permeability and Lipid Peroxidation , and Decreased Levels of Superoxide Dismutase and Catalase content in a trusted digital archive. We use information technology and tools to increase . J. Exp. Bot. 32, 
614

615

616

617

618

619

620

621

622

93-101 (1981).

87. Egley, G. H., Paul, R. N., Vaughn, K. C. \& Duke, S. O. Role of peroxidase in the development of water-impermeable seed coats in Sida spinosa L. Planta 157, 224-232 (1983).

88. Drotar, A., Phelps, P. \& Fall, R. Evidence for glutathione peroxidase activities in cultured plant cells. Plant Sci. 42, 35-40 (1985).

Table 1 Effect of seed priming on seedling emergence and seedling vigour of DSR (pooled over 2019 and 2020)

\begin{tabular}{|c|c|c|c|c|c|}
\hline \multirow[t]{2}{*}{ Treatment } & $\begin{array}{l}\text { TSE } \\
\text { (days) }\end{array}$ & $\mathrm{E}_{50}$ (days) & MET (days) & \multirow[t]{2}{*}{ EI } & \multirow[t]{2}{*}{ VI } \\
\hline & \multicolumn{3}{|c|}{ 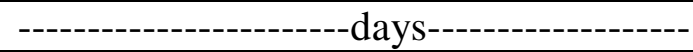 } & & \\
\hline $\mathrm{T}_{1}$ & $3.8 \mathrm{a}$ & $5.8 \mathrm{a}$ & $6.19 a$ & $13.5 \mathrm{f}$ & $969 f$ \\
\hline $\mathrm{T}_{2}$ & $3.2 b$ & $5.1 \mathrm{bc}$ & $5.26 b c$ & $17.5 \mathrm{e}$ & $1290 \mathrm{e}$ \\
\hline $\mathrm{T}_{3}$ & $3.3 b$ & $4.9 \mathrm{bc}$ & $5.06 \mathrm{bc}$ & $20.1 \mathrm{c}$ & $1519 d$ \\
\hline $\mathrm{T}_{4}$ & $3.3 b$ & $4.9 \mathrm{bcd}$ & $5.15 b c$ & $17.6 \mathrm{e}$ & $1590 \mathrm{~cd}$ \\
\hline $\mathrm{T}_{5}$ & $3.2 b$ & $4.7 \mathrm{~cd}$ & $5.49 b$ & 18.1de & $1221 \mathrm{e}$ \\
\hline $\mathrm{T}_{6}$ & $2.7 \mathrm{c}$ & $4.7 \mathrm{de}$ & $4.96 \mathrm{bc}$ & $19.4 \mathrm{~cd}$ & $1643 c$ \\
\hline $\mathrm{T}_{7}$ & $2.7 \mathrm{c}$ & $4.4 \mathrm{e}$ & $4.72 c$ & $20.4 b c$ & $1796 b$ \\
\hline $\mathrm{T}_{8}$ & $2.2 \mathrm{~d}$ & $4.0 \mathrm{f}$ & $4.61 c$ & $22.4 \mathrm{a}$ & $2057 \mathrm{a}$ \\
\hline
\end{tabular}

TSE - time to start emergence, $\mathrm{E}_{50}$ - time taken to reach to $50 \%$ emergence, MET - mean emergence time, EI - emergence index, VI - Vigour index

$\mathrm{T}_{1}$ - hydro priming or control, $\mathrm{T}_{2}$ - sodium selenite at $50 \mu \mathrm{mol}, \mathrm{T}_{3}$ - sodium selenate at 50 $\mu \mathrm{mol}, \mathrm{T}_{4}$ - sodium selenite at $50 \mu \mathrm{mol}+$ sodium selenate at $50 \mu \mathrm{mol}, \mathrm{T}_{5}-\mathrm{ZnO}-\mathrm{NPs}$ at 10 $\mu \mathrm{mol}, \mathrm{T}_{6}-\mathrm{ZnO}-\mathrm{NPs}$ at $10 \mu \mathrm{mol}+$ sodium selenite at $50 \mu \mathrm{M}, \mathrm{T}_{7}-\mathrm{ZnO}-\mathrm{NPs}$ at $10 \mu \mathrm{M}+$ sodium selenate at $50 \mu \mathrm{M}$, T8 - ZnO-NPs $10 \mu \mathrm{M}+$ sodium selenite at $50 \mu \mathrm{M}+$ sodium selenate at $50 \mu \mathrm{Ml}^{-1}$

Means not sharing a letter in common differ significantly at 5\% probability level by HSD Tukey's test. 
642

643

644

645

646

647

648

649

650 
651 Table 2 Effect of seed priming on total chlorophyll, phenolics and soluble protein contents

652 ( $\mathrm{mg} \mathrm{g}^{-1}$ fresh weight) in direct-seeded rice seedlings

653

\begin{tabular}{|c|c|c|c|}
\hline Treatment & Total chlorophyll & Total phenolics & Soluble protein \\
\hline \multicolumn{4}{|l|}{ Year } \\
\hline YI & $4.56 n$ & $0.55 \mathrm{~g}$ & $0.28 \mathrm{k}$ \\
\hline YII & $4.49 \mathrm{o}$ & $0.54 \mathrm{~g}$ & $0.28 \mathrm{k}$ \\
\hline \multicolumn{4}{|l|}{ Treatment } \\
\hline $\mathrm{T} 1$ & $5.40 \mathrm{~h}$ & $0.50 \mathrm{f}$ & $0.17 \mathrm{j}$ \\
\hline $\mathrm{T} 2$ & $5.28 \mathrm{~h}$ & $0.52 \mathrm{ef}$ & $0.25 \mathrm{i}$ \\
\hline $\mathrm{T} 3$ & $4.68 \mathrm{i}$ & $0.54 \mathrm{def}$ & $0.30 \mathrm{gh}$ \\
\hline $\mathrm{T} 4$ & $4.48 \mathrm{j}$ & $0.56 \mathrm{de}$ & $0.31 \mathrm{gh}$ \\
\hline T5 & $4.26 \mathrm{k}$ & $0.55 \mathrm{de}$ & $0.25 \mathrm{i}$ \\
\hline T6 & $4.17 \mathrm{k}$ & $0.54 \mathrm{def}$ & $0.26 \mathrm{hi}$ \\
\hline $\mathrm{T} 7$ & 4.091 & $0.56 \mathrm{de}$ & $0.35 \mathrm{fg}$ \\
\hline $\mathrm{T} 8$ & $3.82 \mathrm{~m}$ & $0.58 \mathrm{~d}$ & $0.36 f$ \\
\hline \multicolumn{4}{|c|}{ Year $\times$ Treatment } \\
\hline YIT1 & $3.84 \mathrm{~g}$ & $0.50 \mathrm{c}$ & $0.17 \mathrm{e}$ \\
\hline YIT2 & $4.19 \mathrm{ef}$ & $0.53 \mathrm{abc}$ & $0.26 \mathrm{bcd}$ \\
\hline YIT3 & $4.46 \mathrm{~cd}$ & $0.54 \mathrm{abc}$ & $0.30 \mathrm{abc}$ \\
\hline YIT4 & $4.75 b$ & $0.56 a b c$ & $0.30 \mathrm{abc}$ \\
\hline YIT5 & $4.19 \mathrm{ef}$ & $0.58 \mathrm{ab}$ & $0.25 \mathrm{cde}$ \\
\hline YIT6 & $4.28 \mathrm{de}$ & $0.55 \mathrm{abc}$ & $0.26 \mathrm{bcd}$ \\
\hline YIT7 & $5.32 \mathrm{a}$ & $0.56 a b c$ & $0.36 \mathrm{a}$ \\
\hline YIT8 & $5.42 \mathrm{a}$ & $0.59 \mathrm{a}$ & $0.36 \mathrm{a}$ \\
\hline YIIT1 & $3.81 \mathrm{~g}$ & $0.50 \mathrm{c}$ & $0.18 \mathrm{de}$ \\
\hline YIIT2 & $3.98 \mathrm{fg}$ & $0.51 b c$ & $0.24 \mathrm{cde}$ \\
\hline YIIT3 & $4.50 \mathrm{~cd}$ & $0.54 a b c$ & $0.31 \mathrm{abc}$ \\
\hline YIIT4 & $4.61 b c$ & $0.55 \mathrm{abc}$ & $0.31 \mathrm{abc}$ \\
\hline YIIT5 & $4.14 \mathrm{ef}$ & $0.52 \mathrm{abc}$ & $0.25 \mathrm{cde}$ \\
\hline YIIT6 & $4.25 \mathrm{e}$ & $0.53 \mathrm{abc}$ & $0.27 b c$ \\
\hline YIIT7 & $5.24 \mathrm{a}$ & $0.56 \mathrm{abc}$ & $0.34 \mathrm{ab}$ \\
\hline YIIT8 & $5.38 \mathrm{a}$ & $0.57 \mathrm{abc}$ & $0.36 \mathrm{a}$ \\
\hline
\end{tabular}

654

655 Means followed by different letters (Tukey ranking) differ significantly at 5\% level of 656 significance. Treatments details are given in Table 1.

657

658

659

660

661 
662 Table 3 Effect of seed priming on total plant uptake $\left(\mathrm{kg} \mathrm{ha}^{-1}\right)$ of primary nutrients and 663 micronutrients by direct-seeded rice

\begin{tabular}{|c|c|c|c|c|c|c|}
\hline Treatment & $\mathrm{N}$ & $P$ & K & B & $\mathrm{Zn}$ & $\mathrm{Si}$ \\
\hline \multicolumn{7}{|l|}{ Year } \\
\hline YI & 1310 & $38.4 \mathrm{k}$ & 68.81 & $21.1 \mathrm{~m}$ & $276 k$ & $162 \mathrm{~m}$ \\
\hline YII & $127 p$ & 37.41 & $66.7 \mathrm{~m}$ & $20.4 n$ & 2661 & $157 n$ \\
\hline \multicolumn{7}{|l|}{ Treatment } \\
\hline $\mathrm{T} 1$ & $109 n$ & $28.9 j$ & $53.8 \mathrm{k}$ & $15.8 \mathrm{k}$ & $206 j$ & 1221 \\
\hline $\mathrm{T} 2$ & $119 m$ & $36.4 \mathrm{~h}$ & $64.2 \mathrm{j}$ & $19.9 i$ & $260 \mathrm{~h}$ & $153 j$ \\
\hline $\mathrm{T} 3$ & 1281 & $38.4 \mathrm{~h}$ & $68.5 \mathrm{ij}$ & $21 \mathrm{i}$ & $275 \mathrm{~h}$ & $162 j$ \\
\hline $\mathrm{T} 4$ & $125 \mathrm{Im}$ & $36.5 \mathrm{~h}$ & $66.9 \mathrm{ij}$ & $10 \mathrm{i}$ & $261 \mathrm{~h}$ & $154 j$ \\
\hline T5 & $118 m$ & $31.7 i$ & $67.3 \mathrm{ij}$ & $17.4 \mathrm{j}$ & $227 i$ & $134 k$ \\
\hline T6 & $137 k$ & $42.5 \mathrm{~g}$ & $69 \mathrm{i}$ & $23.2 \mathrm{~h}$ & $304 \mathrm{~g}$ & $178 \mathrm{i}$ \\
\hline $\mathrm{T} 7$ & $141 \mathrm{k}$ & $43.8 \mathrm{fg}$ & $73.6 \mathrm{~h}$ & $24.0 \mathrm{~g}$ & $313 g$ & $184 \mathrm{hi}$ \\
\hline $\mathrm{T} 8$ & $153 j$ & $44.9 f$ & $78.7 \mathrm{~g}$ & $24.6 \mathrm{~g}$ & $321 \mathrm{~g}$ & $188 \mathrm{~h}$ \\
\hline \multicolumn{7}{|c|}{ Year $\times$ Treatment } \\
\hline YIT1 & $121 \mathrm{fg}$ & $29.2 \mathrm{e}$ & $56.6 \mathrm{ef}$ & $16.0 f$ & $208 f$ & $124 \mathrm{fg}$ \\
\hline YIT2 & $97 i$ & $36.8 \mathrm{c}$ & $51.0 f$ & $20.2 d$ & $264 d$ & $155 d$ \\
\hline YIT3 & 127 efg & $38.9 b c$ & $69.2 \mathrm{~cd}$ & $21.3 \mathrm{~cd}$ & $279 c d$ & $120 \mathrm{~g}$ \\
\hline YIT4 & $129 \mathrm{def}$ & $37.3 c$ & $70.0 \mathrm{~cd}$ & $20.5 d$ & $268 d$ & $165 \mathrm{bcd}$ \\
\hline YIT5 & $130 \mathrm{def}$ & 32.1de & $78.7 a$ & 17.7ef & 231ef & $158 d$ \\
\hline YIT6 & $132 \mathrm{def}$ & $43.1 \mathrm{a}$ & 63.4de & 23.6ab & $310 a b$ & 137ef \\
\hline YIT7 & $136 \mathrm{cde}$ & $44.5 a$ & $70.1 \mathrm{bcd}$ & 24.5ab & $318 a b$ & $180 a b$ \\
\hline YIT8 & $156 a$ & $45.6 a$ & $78.5 a$ & $25.1 a$ & $327 a$ & $187 a$ \\
\hline YIIT1 & 116gh & $28.6 e$ & $64.2 d$ & $15.6 f$ & $204 f$ & $191 a$ \\
\hline YIIT2 & $122 \mathrm{fg}$ & $36.0 \mathrm{~cd}$ & $64.2 d$ & 19.6de & 256de & 151de \\
\hline YIIT3 & 129def & $38.0 b c$ & $67.8 \mathrm{~cd}$ & $20.7 c d$ & $271 \mathrm{~cd}$ & $159 c d$ \\
\hline YIIT4 & $121 \mathrm{fg}$ & $35.7 \mathrm{~cd}$ & $63.8 \mathrm{~d}$ & $19.5 \mathrm{de}$ & 254de & 150de \\
\hline YIIT5 & 106hi & $31.3 e$ & $55.9 f$ & $17.1 f$ & $223 f$ & $131 \mathrm{fg}$ \\
\hline YIIT6 & $142 \mathrm{bcd}$ & 41.9ab & 74.7abc & $22.8 \mathrm{bc}$ & $298 b c$ & $176 a b c$ \\
\hline YIIT7 & $146 a b c$ & $43.2 \mathrm{a}$ & 77.1ab & 23.5ab & $308 a b$ & $181 \mathrm{ab}$ \\
\hline YIIT8 & $150 a b$ & $44.2 \mathrm{a}$ & $78.9 a$ & 24.1ab & $315 a b$ & $185 a$ \\
\hline
\end{tabular}

665 Means followed by different letters (Tukey ranking) differ significantly at 5\% level of 666 significance. Treatments detail in Table 1. 
676 Table 4 Effect of seed priming on yield and yield components of direct-seeded rice in a field 677 experiment during 2019 and 2020

678

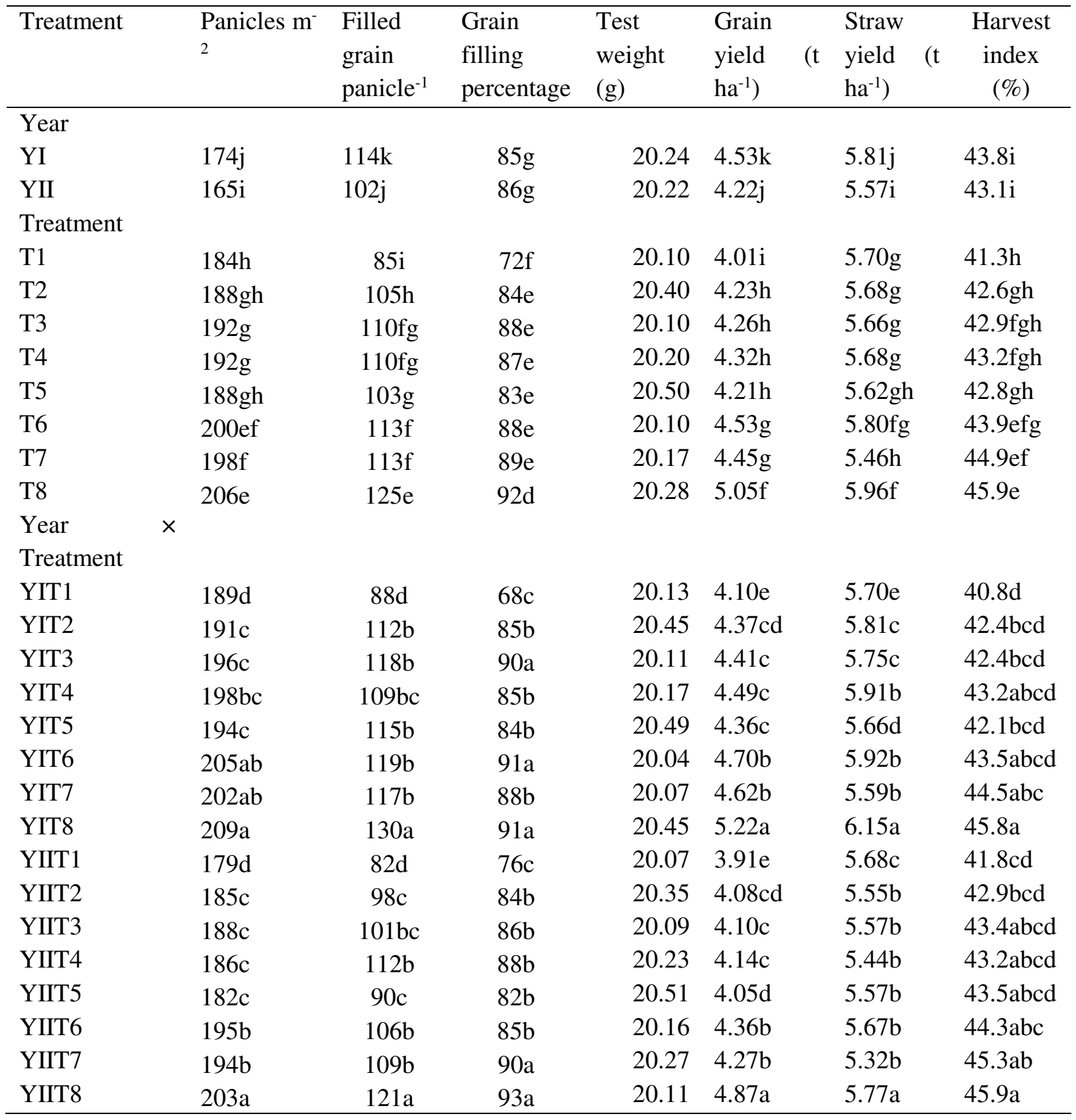
probability. Treatments detail in Table 1. 

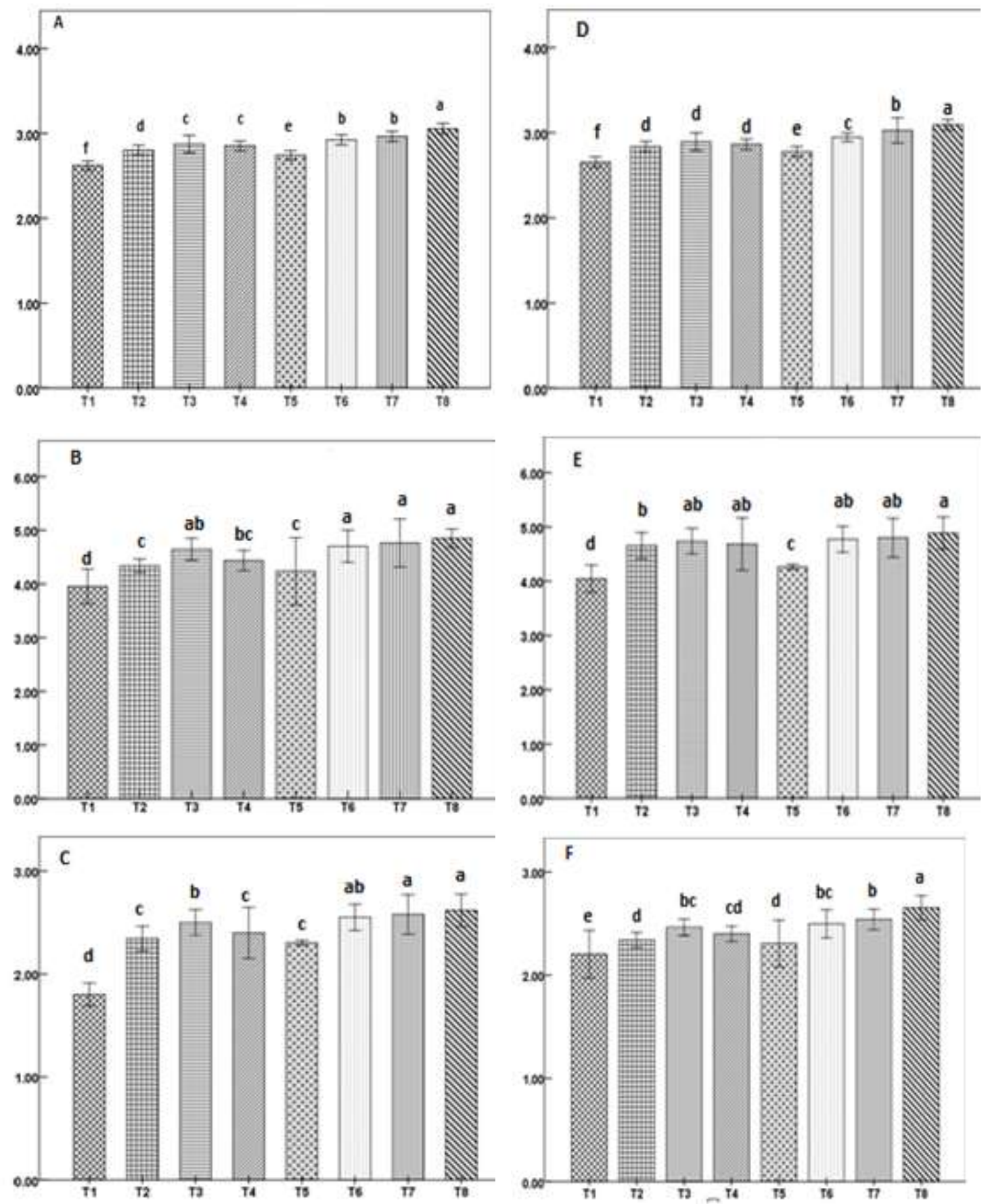

Figure 1 Leaf area index of direct-seeded rice plants during vegetative (A, D), reproductive $(\mathrm{B}, \mathrm{E})$, and ripening $(\mathrm{C}, \mathrm{F})$ stages as affected by seed priming treatments in 2019 (A, B, C) and $2020(\mathrm{D}, \mathrm{E}, \mathrm{F})$

Treatments with different letters (top of bars) represent significant differences $(\mathrm{P}<0.05)$ between treatments. Vertical lines with caps are \pm standard error of the mean. Treatments details are given in Table 1 

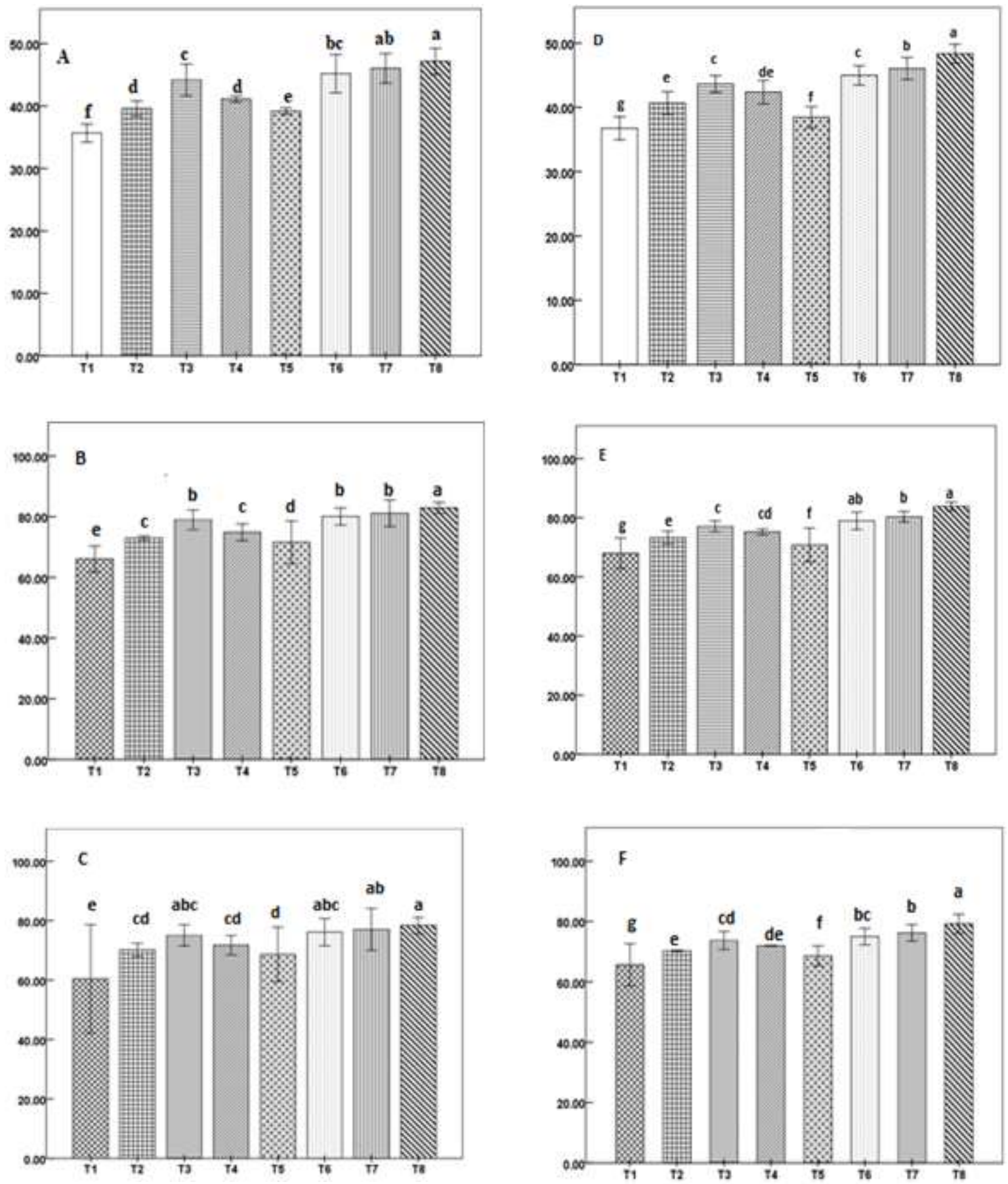

Figure 2 Leaf area duration of direct-seeded rice plants during vegetative (A,D), reproductive (B, E), and ripening (C, F) stages as affected by seed priming in 2019 (A, B, C) and 2020 (D, E, F)

Treatment bars with different letters represent significant differences $(\mathrm{P}<0.05)$ between means. Vertical lines with caps are \pm standard error of the mean of treatments. Treatments details are given in Table 1 

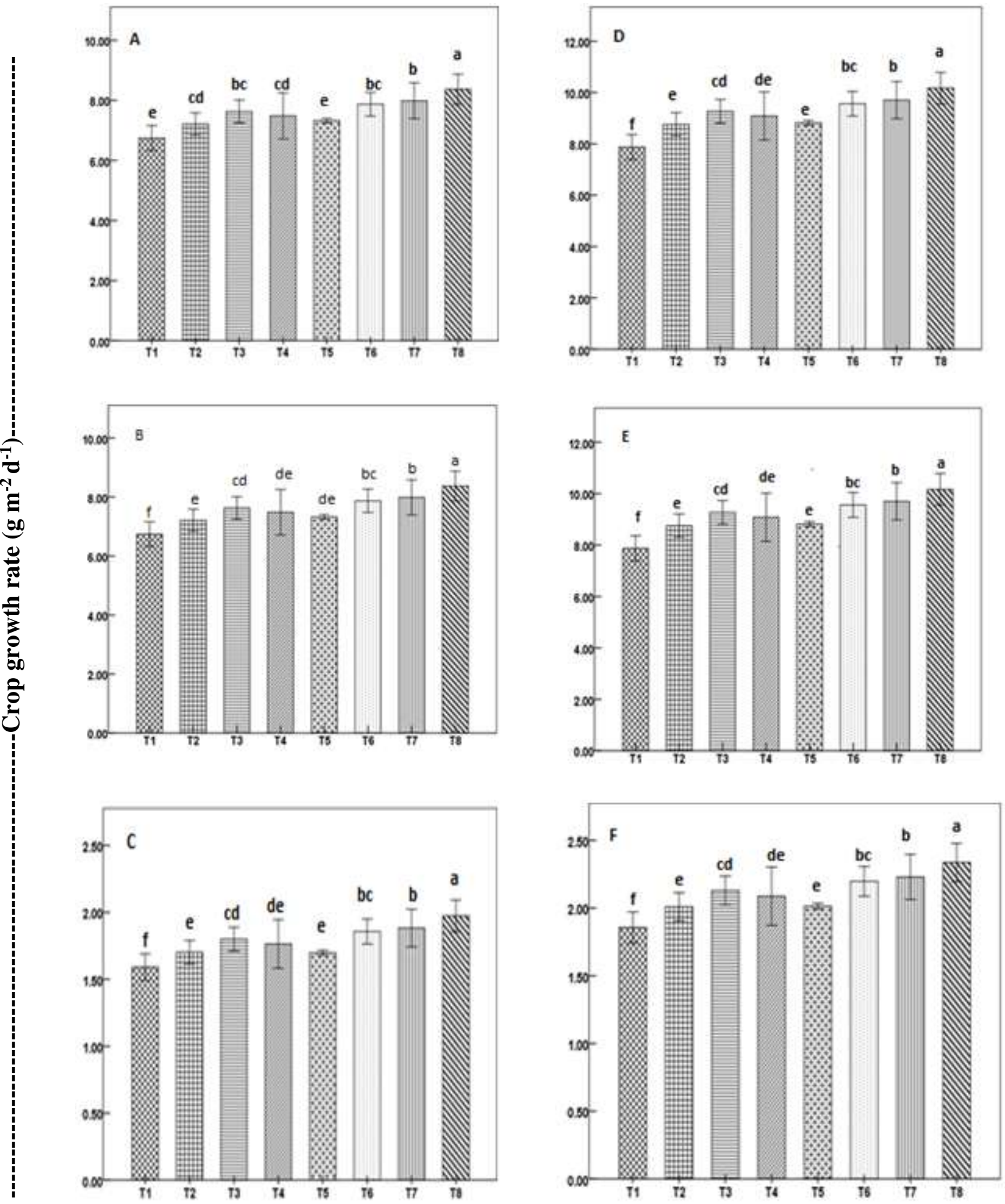

Figure 3 Crop growth rate of direct-seeded rice during vegetative (A, D), reproductive (B, E), and ripening $(\mathrm{C}, \mathrm{F})$ stages as affected by seed priming in 2019 (A, B, C) and 2020 (D, E, F)

Treatment bars with different letters represent significant differences $(\mathrm{P}<0.05)$ between means. Vertical lines with caps are \pm standard error of the mean of treatments. Treatments details are given in Table 1 

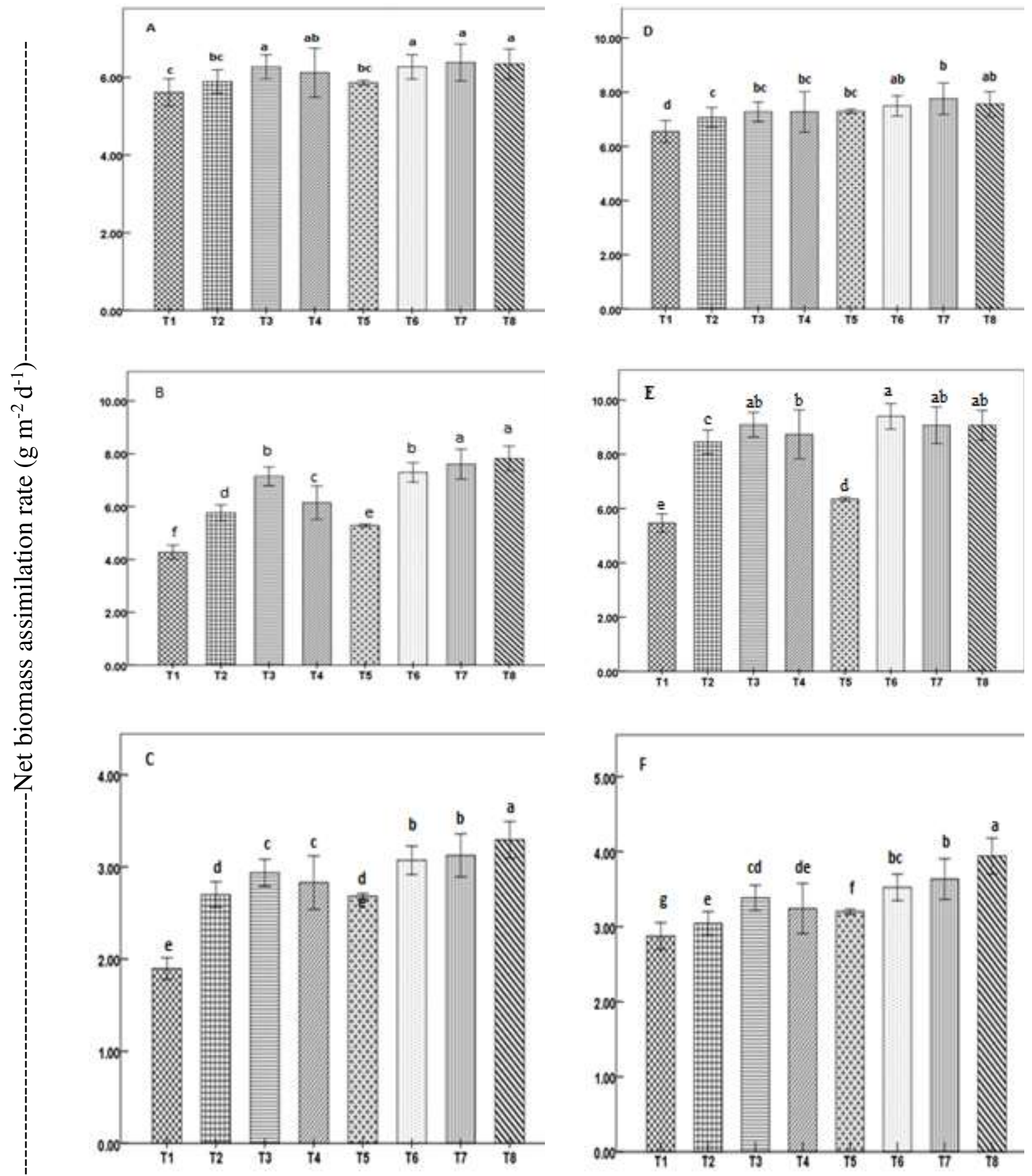

Figure 4 Net biomass assimilation rate by direct-seeded rice plants during vegetative (A, D), reproductive $(B, E)$, and ripening $(C, F)$ stages as affected by seed priming in 2019 (A, B, C) and 2020 (D, E, F)

Treatment bars with different letters represent significant differences $(\mathrm{P}<0.05)$ between means. Vertical lines with caps are \pm standard error of the mean of treatments.

Treatments details are given in Table 1 
708 The authors declare that they have no known competing financial interests or personal

709 relationships that could have appeared to influence the work reported in this paper.

710

711 The authors declare the following financial interests/personal relationships which may be 712 considered as potential competing interests.

713

714 Authors have necessary permissions or licenses to collect plant/seed used in this study. 


\section{Supplementary Files}

This is a list of supplementary files associated with this preprint. Click to download.

- SupplementaryFile.docx 